\title{
THE DYNAMICS OF SAVINGS MOBILISATION IN LESOTHO
}

\section{Bongile Simelane}

Department of Economics, University of South Africa, E-mail: Bongiled@uniswa.sz.

\author{
Nicholas M. Odhiambo* \\ Department of Economics, University of South Africa, E-mail: odhianm@unisa.ac.za / \\ nmbaya99@yahoo.com
}

(Received: March 2019; Accepted: June 2019; Published: August 2019)

\begin{abstract}
This paper provides a conceptual analysis of the dynamics of savings in Lesotho for the period 1960 to 2017. The study is motivated by the low and sometimes negative savings rate and the declining level of economic growth prevailing in Lesotho during the period from 1960 to 2017.The study analyses the behaviour of savings in Lesotho, using the savings trends for the country ever since it obtained independence in 1966.The study further examines the policies that the government of Lesotho has implemented in order to promote savings in the country. The government adopted a policy on rural savings and credit schemes as a means of promoting savings in Lesotho. The purpose of the policy is to improve access to credit for the rural population. The study has identified some challenges that impede savings mobilization in Lesotho. The major savings challenge in Lesotho is the lack of banking facilities in rural areas.
\end{abstract}

Keywords: Savings, Economic Growth, GDP, Lesotho.

\section{JEL Codes: E2}

\section{Introduction}

The role of savings in promoting economic growth has long been recognized by economists in empirical studies. However, the relationship between these two has created controversy among researchers and policymakers. Some researchers believe in the capitalist fundamentalist's view that savings are important for economic growth. Other researchers agree with the Keynesian theory that savings rely on economic growth.

\footnotetext{
${ }^{*}$ Corresponding author: Nicholas M. Odhiambo.E-mail: odhianm@unisa.ac.za
}

Copyright @ 2019 The Author(s). Published by VGWU Press

This is an Open Access article distributed under the terms of the Creative Commons Attribution License - Non Commercial - NoDerivs License (http://creativecommons.org/licenses/by-nc-nd/3.0/) which permits unrestricted use, distribution, and reproduction in any medium, provided the original author and source are credited.

92 Studia Universitatis "Vasile Goldis" Arad. Economics Series Vol 29 Issue 3/2019 ISSN: 1584-2339; (online) ISSN: $2285-3065$

Web: publicatii.uvvg.ro/index.php/studiaeconomia. Pages $92-108$ 
Simelane, B., Odhiambo, N.M., (2019)

The dynamics of savings mobilisation in Lesotho

Solow (1956) was the first researcher to highlight the role of savings in economic growth. Other studies that supported Solow include among others; McKinnon (1973) and Shaw (1973), Sinha and Sinha (1998), Jappelli and Pagano (1994), Alguacil et al. (2004), and Bankole et al. (2013). The life-cycle hypothesis postulated by Modigliani (1970) also found the same results as Solow (1956). The study found that higher economic growth rates tend to raise the lifetime wealth of young working savers compared to the older generation, which is dis-saving. This raises the domestic savings of a country, which boosts investment and accelerates economic growth (Odhiambo, 2009).

The Keynesian hypothesis, on the other hand, stresses that savings depend on the growth of output. Carroll and Weil (1994) were the first to suggest that economic growth precedes savings. Supporters of this theory include Gavin et al. (1997), Saltz (1999), Agarwal (2001), Sekantsi and Kalebe (2015), among others.

Overall empirical studies on the relationship between savings and growth remain inconclusive, especially in developing countries. Very few studies have been done in Lesotho to assess the dynamics of savings. The study analyses the behaviour of savings in Lesotho using saving trends and identifying policies that the government of Lesotho has implemented in order to promote savings. Lastly, the study outlines some challenges that impede savings mobilization in Lesotho.

\section{A Review of Savings Behaviour in Lesotho}

\subsection{Gross Domestic Savings in Lesotho}

Domestic saving rates in Lesotho are not only low, but have shown a systematic decline in the past thirty years. This decline not only retards the economic growth of the country, but also makes it excessively dependent on foreign capital inflows to finance its investment, which then leaves it vulnerable to external shocks and changes in investor sentiment towards developing countries (Kalebe, 2015).

Gross domestic saving in Lesotho has been negative since the country gained independence in 1966 (World Bank, 2004)._This is due to the fact that Basotho migrant labourers working in the South African mines form a significant part of Lesotho's total labour force. These migrant workers hold bank accounts in South Africa where their salaries are deposited by their employers. These miners, therefore, keep their savings in these bank accounts. As a result, significant amounts of Basotho savings are held in South African commercial banks (Mowatt and Zulu, 1999).

Lesotho's negative savings rate is part of a trend common in most African countries. Table 1 shows that the ratio of gross domestic savings to GDP averaged $-28.40 \%$ in the period 1960 to 1969 and it declined further in the period 1980 to 1989 , where it averaged 
Simelane, B., Odhiambo, N.M., (2019)

The dynamics of savings mobilisation in Lesotho

$-79.07 \%$. The savings average improved to $-42.88 \%$ in the period 1990 to 1999 and then improved to around $-23.75 \%$ during the period 2010-2017 (Central Bank of Lesotho, 2017).

Table 1 Gross Domestic Savings Rate in Lesotho (1960 -2017)

\begin{tabular}{|c|c|c|c|c|c|c|}
\hline Years & $\mathbf{1 9 6 0 - 6 9}$ & $\mathbf{1 9 7 0 - 7 9}$ & $\mathbf{1 9 8 0 - 8 9}$ & $\mathbf{1 9 9 0 - 9 9}$ & $\mathbf{2 0 0 0 - 2 0 0 9}$ & $\mathbf{2 0 1 0 - 2 0 1 7}$ \\
\hline $\begin{array}{c}\text { Gross Domestic } \\
\text { Savings / GDP }\end{array}$ & -28.40 & -54.29 & -79.07 & -42.88 & -45.89 & -23.75 \\
\hline
\end{tabular}

Source: World Bank Development reports (1970 - 2017),

Central Bank of Lesotho annual reports $(1977$ - 2017)

Table 1 further shows that gross domestic savings as a percentage of GDP improved from an average of about $-79 \%$ in the 1980 s to $-42 \%$ in the 1990 s and beyond 2000. The improvement in gross domestic savings in the 1990s in Lesotho was a result of government initiatives to lower government expenditure, coupled with an increase in private savings (Kalebe, 2015).

\subsection{Current Usage of Savings Products in Lesotho}

According to a survey conducted by the Centre for Financial Regulation and Inclusion diagnostic report in 2014 for Lesotho, saving is a widespread practice among Basotho adults. This is illustrated in Figure 1, which shows that about 50\% of adults in Lesotho save through formal or informal savings institutions; while about 7\% of adults keep their savings at home (Centre for Financial Regulation and Inclusion in Lesotho, 2014).

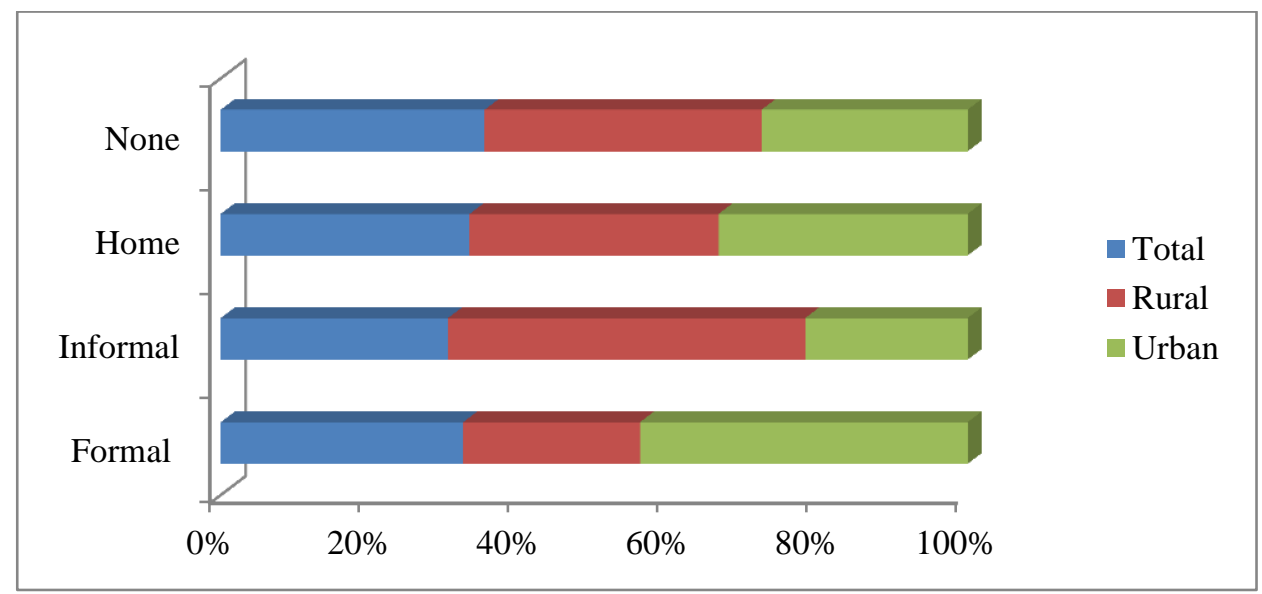

Figure 1 Savings Mechanisms / Products (\% of adult usage)

Source: Centre for Financial Regulation and Inclusion (2014) 
Simelane, B., Odhiambo, N.M., (2019)

The dynamics of savings mobilisation in Lesotho

Figure 1 also shows that the level of formal savings is significantly higher among the urban population in Lesotho. Urban savings rates are about 50\%, compared to $27 \%$ in rural areas. According to the Centre for Financial Regulation and Inclusion in Lesotho (2014), the difference is explained by relatively higher savings rates in formal financial institutions in the urban areas (51\%) as opposed to about 25\% in the rural areas. This means that in Lesotho the urban population has more access to formal savings institutions compared to the rural population. This is borne out by the fact that a large proportion of salaried workers reside in urban areas where they have greater access to formal financial and savings institutions (Centre for Financial Regulation and Inclusion, 2014).

Basotho people use multiple forms of saving. They save with banks, community savings groups and at home. The study by the Centre for Financial Regulation and Inclusion in Lesotho (2014) estimated that about $45 \%$ of savers in Lesotho diversify their savings. That is, about half of Basotho adults that save in informal savings schemes also save in the formal financial institutions (Centre for Financial Regulation and Inclusion, 2014). Figure 2 shows that formal savings in Lesotho dominate when compared to the informal savings institutions.

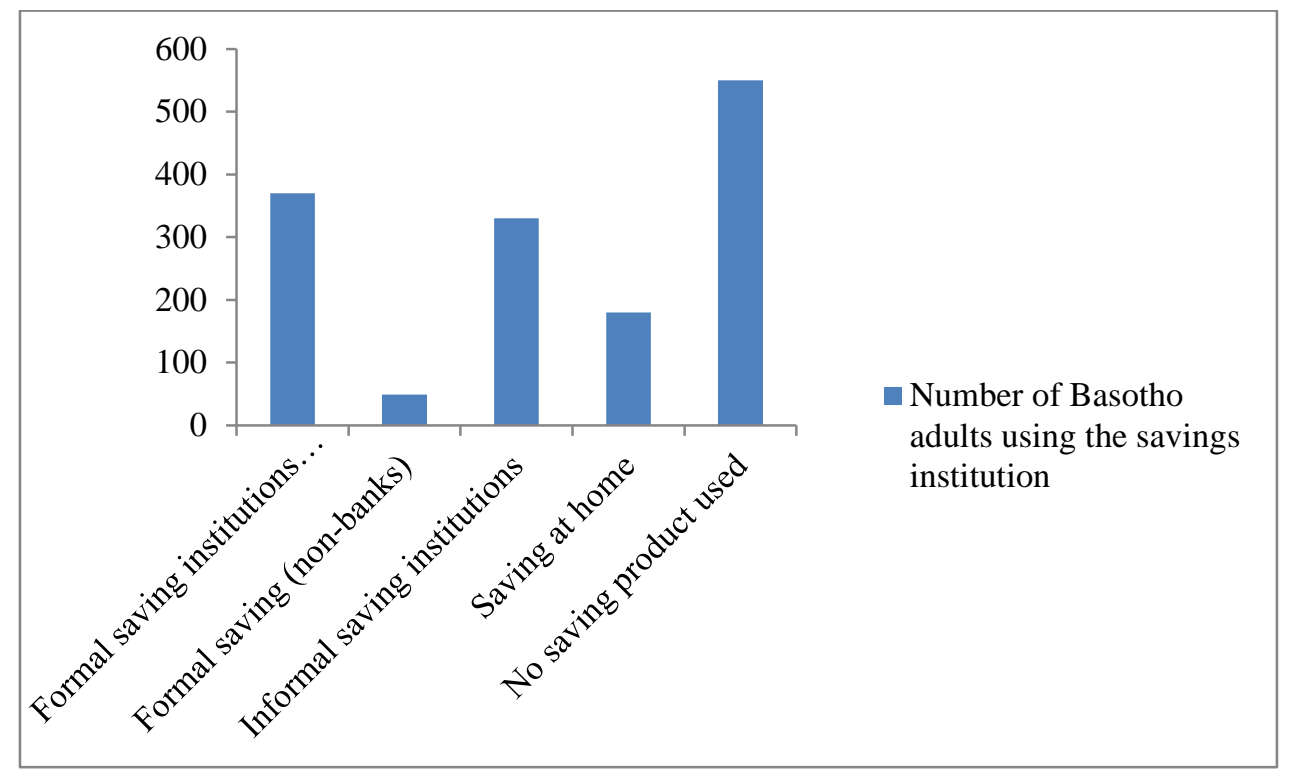

Figure 2 Adults Usage of Savings Institutions

Source: Centre for Financial Regulation and Inclusion (2014) 
Simelane, B., Odhiambo, N.M., (2019)

The dynamics of savings mobilisation in Lesotho

When comparing the different income groups in Lesotho with the savings channels available, the Centre for Financial Regulation and Inclusion (2014) study came up with the results shown in Figure 3.

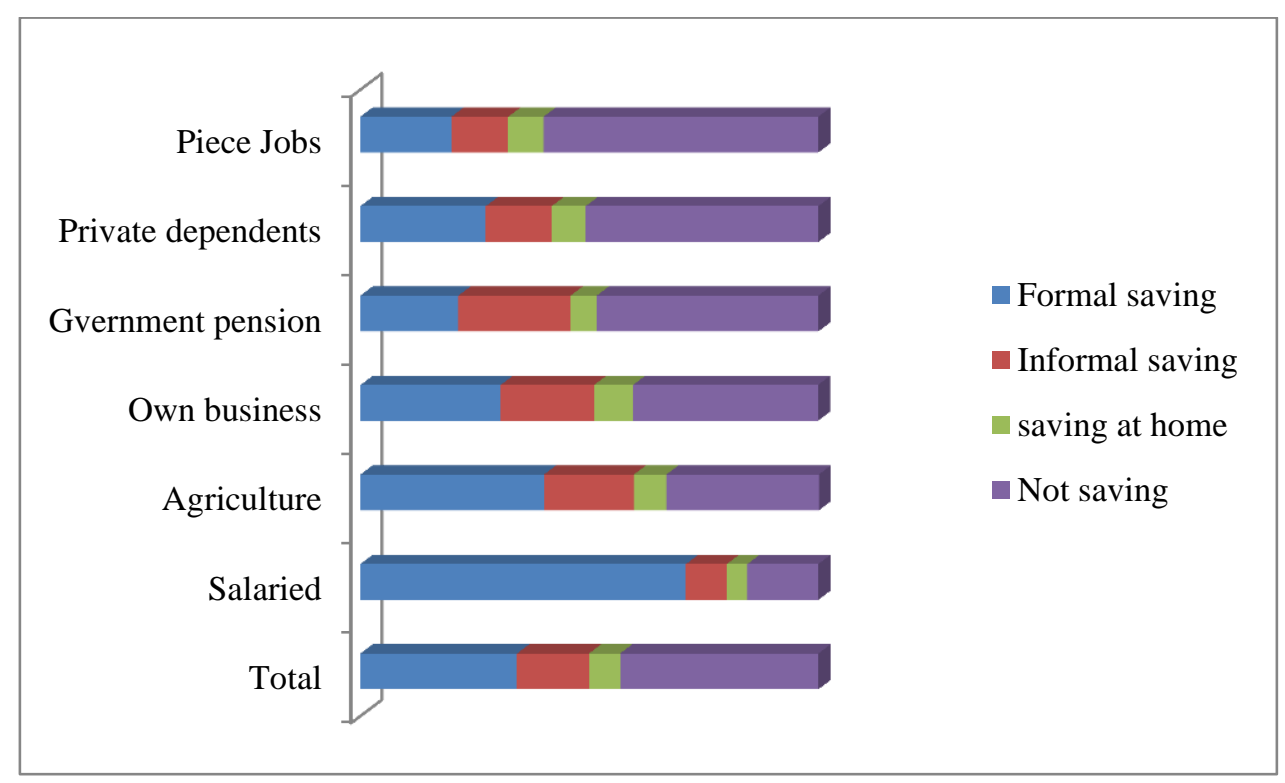

Figure 3 The Use of Savings Products by Different Income Groups in Lesotho Source: Centre for Financial Regulation and Inclusion (2014)

Figure 3 shows that the level of savings in Lesotho varies considerably across the different income groups. The figure shows a positive relationship between savings and the income levels in Lesotho. Figure 3 also shows that over $70 \%$ of salaried workers save in formal savings institutions. By comparison, only about $20 \%$ of piece job workers, who have the lowest income, save in formal saving institutions. Figure 3 also shows that about $60 \%$ of piece job workers are unable to save at all (Centre for Financial Regulation and Inclusion in Lesotho, 2014).

The formal financial institutions in Lesotho offer their services to a diverse kind of customer. Only a third of salaried workers save in financial institutions, while about two- thirds diversify their savings across the other non-bank financial institutions (Centre for Financial Regulation and Inclusion in Lesotho, 2014). This is represented by the pie chart in Figure 4. 


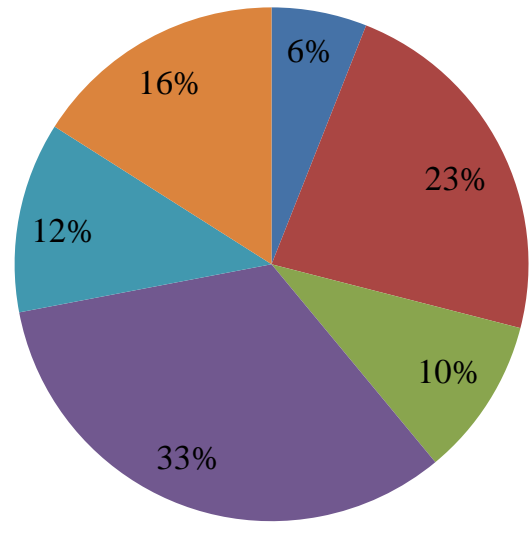

- Government pension dependents

- Private dependents

Piece jobs

- Salaried workers

- Own business

- Agriculture

\section{Figure 4 A Breakdown of Bank Clients Between Target Markets}

Source: Centre for Financial Regulation and Inclusion (2014)

It is worth noting that when comparing savings within the formal and informal saving institutions, the proportion of each income group's saving with the formal financial institutions is strongly related to income, while the proportion saving with the informal sector is weakly related to income level. This shows that higher income groups in Lesotho do not save only with financial institutions, but diversify their savings to other non-bank savings institutions as well.

\section{The Performance of Savings Providers in Lesotho}

Savings providers in Lesotho comprise two types: the formal savings providers and the informal savings providers. The formal savings institutions are basically the commercial banks in the country. The informal savings institutions, on the other hand, comprise cash loan operators, money lenders, community-based savings and credit organisations and burial societies. The performance of these savings providers are described in detail in the following subsections:

\subsection{Commercial Bank Performance in Lesotho}

The performance of Lesotho's commercial banks can be explained using the combined balance sheet for selected years presented in Table 2 below. 
Simelane, B., Odhiambo, N.M., (2019)

The dynamics of savings mobilisation in Lesotho

\begin{tabular}{|l|r|r|r|r|}
\multicolumn{5}{|c}{ Table 2 Lesotho: Balance Sheet for the Commercial Banks } \\
\hline Cash & $\mathbf{1 9 9 9}$ & $\mathbf{2 0 0 0}$ & $\mathbf{2 0 0 1}$ & $\mathbf{2 0 0 2}$ \\
Balance with CBL & 35.8 & 50.4 & 51.8 & 54.3 \\
Balance with local banks & 538 & 458.2 & 76.4 & 147.7 \\
Balance with banks abroad & 0.1 & 2.4 & 3.2 & 50.8 \\
Marketable securities & 393.8 & 439.2 & 480.3 & 349.0 \\
Investment in subsidiary & 652.2 & 818.7 & $1,073.8$ & $1,215.2$ \\
Gross Loans \& Advances & 0 & 0.0 & 0.8 & 0.8 \\
Provisions & 237.3 & 223.8 & 272.8 & 318.5 \\
Net Loans & 20.9 & 26.0 & 25.6 & 32.5 \\
Fixed Assets & 216.4 & 197.9 & 247.1 & 286.0 \\
Other Assets & 70.4 & 102.8 & 108.0 & 103.4 \\
Total Assets & 42.5 & 51.5 & 102.2 & 117.8 \\
Balances due to local banks & $\mathbf{1 , 9 4 9 . 2}$ & $\mathbf{2 , 1 2 1 . 0}$ & $\mathbf{2 , 1 4 3 . 6}$ & $\mathbf{2 , 3 2 5 . 0}$ \\
Balances due to banks abroad & 61.2 & 92.3 & 0.0 & 22.6 \\
Deposits & 23.4 & 68.3 & 60.5 & 70.0 \\
Demand deposits & $1,640.4$ & $1,629.4$ & $1,744.7$ & $1,923.0$ \\
Savings deposits & 523.5 & 555.7 & 669.5 & 841.8 \\
Time deposits & 520.6 & 492.8 & 521.9 & 561.5 \\
Deferred pay accounts & 558.4 & 529.4 & 513.2 & 519.6 \\
Other liabilities & 37.9 & 51.5 & 40.1 & 0.0 \\
Minority shareholder interest & 86.3 & 170.4 & 158.0 & 123.9 \\
Share capital & 0 & 0.0 & 17.7 & 17.2 \\
Other reserves & 36.5 & 36.5 & 36.5 & 36.5 \\
Net worth & 101.4 & 124.1 & 126.2 & 131.7 \\
Liabilities \& Net worth & 137.9 & 160.6 & 162.7 & 168.2 \\
Contingencies \& commitments & $\mathbf{1 , 9 4 9 . 2}$ & $\mathbf{2 , 1 2 1 . 0}$ & $\mathbf{2 , 1 4 3 . 6}$ & $\mathbf{2 , 3 2 5 . 0}$ \\
\hline
\end{tabular}

Source: World Bank (2004)

Table 2 shows that Lesotho banks had about M2.3 billion (equivalent to US $\$ 290$ million) in total assets in 2002. Total deposits in the same year were M1.92 billion (equivalent to US\$242 million), which represents about 30\% of GDP. This is relatively high when compared to other African countries (World Bank, 2004).

Deposits represented an increasing percentage of the commercial banks' funds in Lesotho. As of December 2002, the non-interest-bearing demand deposits represented $44 \%$ of total deposits as compared to $32 \%$ in 1999. Time deposits in Lesotho, which normally have a maturity of three to six months, showed a decrease of about 30\% in December 2002, compared to 34\% in 1999 (Central Bank of Lesotho, 2003).

98 S sciendo Studia Universitatis "Vasile Goldis" Arad. Economics Series Vol 29 Issue 3/2019 ISSN: 1584-2339; (online) ISSN: 2285 - 3065

Web: publicatii.uvvg.ro/index.php/studiaeconomia. Pages $92-108$ 
Simelane, B., Odhiambo, N.M., (2019)

The dynamics of savings mobilisation in Lesotho

Savings deposits, on the other hand, showed a decline of about $29 \%$ of total deposits compared to $32 \%$ in 1999 . Inflation over the four-year period averaged $6.5 \%$. This is why the ratio of gross domestic saving to GDP is reported to be negative in Lesotho since the country gained independence, as shown in Table 1.

Of note is that the Lesotho banks' holdings in banks abroad represent about $15 \%$ of total assets, and this is considerably larger than the loan portfolio. A large percentage of marketable securities (52\% of total assets) were also invested outside Lesotho. This was largely because all the foreign commercial banks in Lesotho have large, stable parent banks in South Africa (Mowatt and Zulu, 1999).

Over the four-year period shown in Table 2, total assets grew on average by $6.1 \%$ per annum, while net loans grew on average by $9.7 \%$ and deposits grew by only $5.4 \%$. However, since inflation over the four-year period averaged $6.5 \%$, total deposits and total assets declined in real terms during the four-year period (International Monetary Fund, 2012).

The composition of the lending system shows that a relatively high percentage (23.1\%) of total loans had a maturity of over one year in the years selected, while at the other end only $1.9 \%$ of total deposits were for a period of over one year. This demonstrates that commercial banks in Lesotho are willing to engage in significant term transformation. Lending is heavily concentrated in terms of credit risk as the 20 largest borrowers accounted for more than $50 \%$ of total loans outstanding as of December 2002. Since Lesotho's lending environment is high-risk, this suggests that commercial banks in Lesotho have pursued highly conservative lending strategies. This has exacerbated the problem of accessing credit in the banking system. Table 2 shows that commercial banks in Lesotho are extremely liquid, with about $25.9 \%$ of total assets invested in cash and about $52.3 \%$ in marketable securities in Lesotho and South Africa (Central Bank of Lesotho, 2012).

\subsection{The Informal Savings Sector/Non-Financial Institutions in Lesotho}

Due to lack of interest by the commercial banks in offering their services to people in the rural areas, the Basotho people have had to rely mainly on the informal sources of finance (International Labour Organisation, 2011). Such informal savings institutions are most often called 'Non-bank Financial Institutions' (NBFIs). The non-bank financial sector in Lesotho is highly diverse, and is made up of an array of deposit-taking and non-deposit-taking institutions, which vary in size, number and the type of financial service they offer (International Monetary Fund, 2012).

The NBFIs in Lesotho are divided into regulated and unregulated informal savings institutions. The regulated savings sector includes pension funds, insurance companies, money lenders, credit-only institutions, collective investment schemes, 
Simelane, B., Odhiambo, N.M., (2019)

The dynamics of savings mobilisation in Lesotho

asset management companies, exchange bureaus, money transfer companies, and insurance brokers and agents (International Monetary Fund, 2012).

Non-bank financial institutions typically target specialized types of savers and investors and in so doing; they are developing their comparative advantages in areas where commercial banks have limited ability to provide adequate services. By extending financial services beyond the range of products or services typically offered by commercial banks, NBFIs increase the competitiveness and efficiency of mobilizing savings in the financial sector as a whole. In fact, NBFIs extend the range of available options and enhance the ability of savers and investors to manage economic risks (World Bank Lesotho Financial Sector Review, 2004). A description of the non-bank financial institutions assets for selected years as compared to the banking sector assets is presented in Table 3:

Table 3 Lesotho Banks \& Non-bank Financial Institutions Assets (\% of GDP)

\begin{tabular}{|l|c|c|c|c|}
\hline \multirow{2}{*}{ Financial Institution } & \multicolumn{2}{|c|}{ Number of Institutions } & \multicolumn{2}{c|}{ Assets as \% of GDP } \\
\cline { 2 - 5 } Financial Cooperatives & $\mathbf{2 0 0 7}$ & $\mathbf{2 0 1 0}$ & $\mathbf{2 0 0 7}$ & $\mathbf{2 0 1 0}$ \\
\hline Collective Investment Schemes & 4 & 4 & 42 & 47.3 \\
Insurance companies & - & 51 & - & 0.4 \\
Pension Funds & 4 & 4 & - & 2.5 \\
Money lenders & - & 7 & 18 & 14.2 \\
Asset management companies & - & 102 & 5 & 14 \\
Exchange Bureaus & - & 2 & - & 0.4 \\
Money transfer companies & - & 2 & - & - \\
Insurance brokers and agents & 8 & 8 & - & - \\
\hline
\end{tabular}

Source: IMF (2012) \& Central Bank of Lesotho (2012)

Table 3 shows that the overall assets of the NBFIs are significant and stood at $31.7 \%$ of GDP in 2010. Insurance and pension funds are the largest two subsectors of the NBFIs, with an asset size equal to $14.2 \%$ and $14 \%$ of GDP, respectively. The assets of NBFIs sector increased by 8.7\% of GDP between 2007 and 2010, 
Simelane, B., Odhiambo, N.M., (2019)

The dynamics of savings mobilisation in Lesotho

compared to 5.3\% of GDP in the formal commercial banking sector. The number of operative NBFIs also increased significantly from 185 in 2007 to 235 in 2010. This shows that this sector is growing much faster than the formal savings sector (IMF, 2012).

\section{Policy on Rural Savings and Credit Schemes in Lesotho}

The central Bank of Lesotho in 1999, adopted a policy on rural savings and credit groups. The objective of the policy is to promote rural financial intermediation throughout Lesotho. It targets the low income and rural communities and advocates a linkage banking program through a savings and credit approach. By linking the informal banking sector with the formal banking sector, the policy is encouraging more savings and borrowing for productive projects and thus improving the standard of living for rural households in Lesotho (Central Bank of Lesotho Annual Report, 2012).

According to the Central Bank of Lesotho Annual Report, 2012, the rationale for the policy is to increase access to credit by providing basic banking services to the target group while increasing their income levels through affordable savings based credit. The policy uses the following strategies to achieve benefits from the policy:

i) The use of Rural Savings and Credit Groups (RSCGs) as avenues through which credit to rural people is delivered.

ii) Legalization of RSCGs through registration under the Societies Act of 1966

iii) Linking the RSCGs with the formal banking sector under a linkage program.

Some progress on the implementation of the policy is that extensive work on sensitization of rural communities in Lesotho has been accomplished with much concentration in the remote part of Lesotho. Communities living in the rural areas have shown great interest in the scheme and are willing to participate (Central Bank of Lesotho Annual Report, 2012).

Other achievements of the policy implementation identified in the Central Bank of Lesotho Annual Report (2012) report include the following:

i) Signing of a Memorandum of Understanding (MOU) between the CBL, on behalf of the Government of Lesotho (GOL) and the participating commercial banks.

ii) The policy has also enabled training of groups to strengthen their financial literacy. This has been achieved in conjunction with efforts by the Ministry of Agriculture and Food Security and the Ministry of Trade and Industry, Cooperatives and Marketing (MTICM) through its department of Cooperatives (UNCTAD, 2013). 
Simelane, B., Odhiambo, N.M., (2019)

The dynamics of savings mobilisation in Lesotho

iii) Establishment of a Credit Guarantee Fund by the CBL amounting to M2.5 million (Central Bank of Lesotho, 2012).

iv) Loans have already been extended to three groups to the value of M81, 030 for purposes of poultry farming (UNCTAD, 2013).

\section{Research Methodology}

Domestic savings is seen by most researchers as a means of increasing investment in an economy, and investment in turn enhances a country's economic growth through capital formation (Kudaisi, 2013). Understanding the behavior of national savings is therefore critical is designing policies that will promote savings, investment and growth especially in developing countries such as Lesotho. The study conceptually analyses the behaviour of savings in Lesotho, using the savings trend and comparing it with the trend for the country's economic growth, covering the period between 1960 to 2017.

Following the Neoclassical growth theories developed by Harrod (1939), Domar (1946) and Solow (1956) which state that the savings rate enhances faster growth in an economy, the current study uses the gross domestic savings to measure the level of savings in Lesotho. Gross savings is used instead of net savings because of the arbitrary nature of capital consumption allowances which vary across countries, and thus it would create problems of comparability of the estimations of this study across countries (Agrawal, 2000).

Economic Growth, on the other hand, is measured by the annual growth rate of real GDP (Solow, 1956). The gross domestic product (GDP) is defined as the value of all final goods and services produced in a country in one year. The annual growth rate of real GDP as a proxy for economic growth is used extensively in many empirical studies such as; Jappelli and Pagano (1994).

Using the descriptive data analysis for the period 1960 to 2017, the study aims to investigate the behavior of savings in Lesotho.

\section{Main Findings}

\subsection{Trend Analysis of Savings in Lesotho}

The level of gross domestic savings as a percentage of GDP in Lesotho in the period 1960 to 2017 has always been negative. This has been a common trend in most African countries. As shown in Figure 5, the ratio of gross domestic savings to GDP averaged $-28.40 \%$ in the period 1960 to 1969 and was worse in the period 1980 to 1989 , where it averaged $-79.07 \%$. It improved to an average of $-42.88 \%$ in the period 1990 to 1999 and it was around $-23.75 \%$ during the period 2010-2017.

102 Sciendo Studia Universitatis "Vasile Goldis" Arad. Economics Series Vol 29 Issue 3/2019 ISSN: 1584-2339; (online) ISSN: 2285 - 3065

Web: publicatii.uvvg.ro/index.php/studiaeconomia. Pages $92-108$ 
Simelane, B., Odhiambo, N.M., (2019)

The dynamics of savings mobilisation in Lesotho

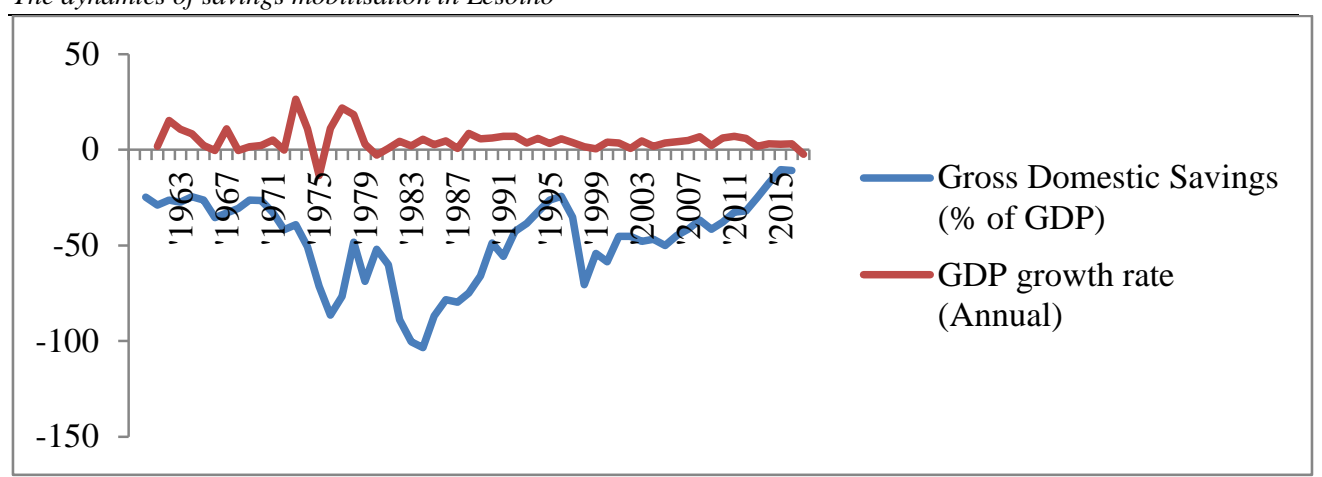

Figure 5 Savings and Economic Growth Trends in Lesotho (1960 - 2017)

Source: World Bank Development Indicators (1960 -2017)

Very little was done by the government of Lesotho to develop the country economically during the colonial era. After attaining political independence in 1966, the government of Lesotho had to intensify efforts in order to build a sound macroeconomic base.

The country's economic performance started off from a low gross domestic product (GDP) of around $\$ 0.06$ billion in the period 1967/1968. It gradually improved to $\$ 0.33$ billion in 1982 . During this period up to the late 1980 's, the economy of Lesotho largely depended on the primary sector where the agricultural sector was the main contributor of economic growth. In 1985, the agricultural sector alone contributed about $21.8 \%$ to the country's GDP, while the manufacturing sector contributed around $9.9 \%$ of GDP.

Lesotho's economic performance has also been largely influenced by developments in its neighboring country, the Republic of South Africa. Prior to 2000 , another factor that contributed much to the country's economic growth was the remittances from migrant workers employed in the South African mines. Remittances generated about $50 \%$ of the country's gross national income (GNI), and this comprised almost half of the male labor force of Lesotho.

In the period between 1988 and 1997, Lesotho recorded its strongest GDP performance amounting to an average of over $6 \%$ (figure 5). A major contributing factor to this huge increase in growth was the public investment in the Lesotho Highlands Water project (LHWP). This is a project developed to tap Lesotho's abundant water resource, its main natural resource, mainly for sale in the Republic of South Africa (AfDB, 2008). Another contributing factor to the improved growth rate was the political uncertainty in South Africa during this period which led to an increase in corporate investment in Lesotho, much of it as a result of efforts to circumvent sanctions. 
Simelane, B., Odhiambo, N.M., (2019)

The dynamics of savings mobilisation in Lesotho

Lesotho's economic performance stagnated in the period between 1997 and 2001. This was mainly due to the completion of the LHWP project, political disturbances in 1998, severe decline in productivity in the agricultural sector and a fall in remittances from mineworkers who worked in the South African Mines. The political disturbances in September 1998 resulted from discontent with the results of the 1998 general elections and this led to the intervention of the Southern Development Community (SADC) troops. The fall in the number of migrant mine workers between 1997 and 1999, in particular, translated into a fall in income for the majority of households in Lesotho In 1997 about 15.5\% of Lesotho's labor force (108,808 Lesotho citizens) was working in the South African mines, but by 1999 that labor force had dropped by more than 50\% to 52,456 (Makoa, 2004).

This period of weak economic growth also coincided with a period where foreign direct investment (FDI) diverted towards the Republic of South Africa as economic sanctions associated with the apartheid era ended. Most FDIs that were previously attracted to Lesotho invested their businesses direct to the RSA. Even those that had established in Lesotho closed down and moved to the RSA and established their businesses there.

Since the turn of the century, the government of Lesotho was successful in capitalizing on the economic partnership agreement between the United States and Africa, in penetrating the American market with its apparel exports. Exports of textiles, propelled by the USA's African Growth and Opportunities Act (AGOA) that allows duty and quota - free access for textile exports into the country, became Lesotho's main engine for growth. Off note, in Lesotho's apparel success story is the government's decision to combine its competitiveness initiative with a series of early stage incentives for investors, an aspect that could be questioned by the neoclassical economists, but has yielded very positive results for Lesotho. Another contributing factor to Lesotho's success story in the apparel trade is the direct engagement of the Lesotho government with the global and regional buyers of apparel and also an overall policy acknowledgement of the rapidly changing structure of the global apparel trade.

Real GDP growth, however, declined to around $2.29 \%$ in 2004 in Lesotho as a result of adverse weather conditions that hit hard on agricultural production. In the same year, the manufacturing sector also experienced a slump in manufacturing output. This was mainly due to investors' concern about how long the duty free access to the USA under AGOA would last. Investors were also worried about the cessation of quotas in January 2005 under the Multi-Fibre Agreement (MFA) (AfDB, 2008).

In the period between 2006 and 2007, Lesotho's economic growth impressively recovered to an average of around $4.7 \%$ in 2007 . This growth recovery was a result of the strong performance of the mining sector where two diamond mines were

104 Sciendo Studia Universitatis "Vasile Goldis" Arad. Economics Series Vol 29 Issue 3/2019 ISSN: 1584-2339; (online) ISSN: $2285-3065$

Web: publicatii.uvvg.ro/index.php/studiaeconomia. Pages $92-108$ 
Simelane, B., Odhiambo, N.M., (2019)

The dynamics of savings mobilisation in Lesotho

opened in that period. The mining sector's contribution to GDP increased from $0.9 \%$ in 2004 to around 4.5\% in 2011 (Central Bank of Lesotho Economic Review, 2012). Another contributing factor to the improved growth rate was the recovery of the manufacturing sector, especially the garment sector which was boosted by the strengthening of the Maloti in 2007. In this period, investor's worries about the future of AGOA were eased following the extension of the third world country fabric provision to 2012 and there was also an imposition of global limitations against Chinese imports until 2008. Other factors that contributed much to the high growth rate in this period were the tax reforms and proactive measures taken by the government of Lesotho in 2006 to address the concerns of the industry sector.

Lesotho's economic growth rate fluctuated around $3.63 \%$ in the period between 1980 and 2004, as depicted in Figure 5. This was mainly due to the construction of the Lesotho Highland Water Project (LHWP), which impacted significantly on the economic growth of Lesotho. In the period 1980-1987, before the LHWP started, Lesotho's growth rate averaged around $2.4 \%$. During the construction phase of the LHWP project (1987-1998), Lesotho's growth rate increased to an average of around $4.9 \%$. The growth rate then declined to around $2.9 \%$ in the period after the project was completed (World Bank, 2004).

Despite the macroeconomic reforms that African countries like Lesotho have attempted in the past decade, there seems to be little evidence of these having a major impact on domestic savings (World Bank, 2004).

\section{Conclusion}

Very few studies have investigated the behaviour of savings in Lesotho. This paper explored the dynamics of savings in Lesotho for the period 1960 to 2017. It traced the savings trends patterns ever since the country gained independence. It identified challenges faced by the country in mobilizing savings. The major savings challenge in Lesotho is the lack of banking facilities in rural areas. Another challenge is the unfavourable mountainous terrain which makes infrastructure development difficult and costly, especially in rural areas. The study also analysed the policies applied by Lesotho in trying to promote savings.

The Lesotho government adopted a policy on rural savings and credit schemes. The policy aims to promote rural financial intermediation in Lesotho. The policy links the informal banking sector with the formal banking sector, thus encouraging more savings mobilization for the population living in the rural areas. However, despite the policy reforms that the government of Lesotho has implemented, there seems to be little evidence of these having a major impact on domestic savings.

A major challenge for mobilizing savings in Lesotho is the limited access to credit in the rural areas. The majority of the financial institutions in Lesotho mainly have 
Simelane, B., Odhiambo, N.M., (2019)

The dynamics of savings mobilisation in Lesotho

branches in urban areas, where the population density is high and where there is easy access to credit for their clients.

\section{Acknowledgements}

We would like to thank the anonymous reviewers and editor of the SUES journal for their valuable contributions that have helped shape up this research paper. Their enthusiasm, knowledge and exacting attention to detail have been an inspiration and kept this research paper on track. I am also grateful to my supervisor, Professor Nicholas Odhiambo, for his generosity and expertise that has improved this study in innumerable ways. Nobody has been more important to me in the pursuit of this research paper than the members of my family. I would like to thank my Mother, whose love and guidance are with me in whatever I pursue. She is the ultimate role model. Most importantly, I wish to thank my loving and supportive husband, Zweli, and my three wonderful children, Kwandokuhle, Siviwe and Siphilangezwi, who provided unending inspiration.

\section{Funding}

This research work would not have been possible without the financial support of the University of South Africa, Department of Economics.

\section{Author's Contributions}

Bongile Simelane and Professor Nicholas Odhiambo conceived the study and were responsible for the entire compilation of the research paper; from designing, data collection, development of the data analysis and interpretation.

\section{Disclosure Statement}

The University of South Africa is the only sponsor who funded the research paper.

\section{References}

1. African Development Bank, (2008), Annual Report.

2. Agrawal, P., (2000), Savings, Investment and Growth in South Asia, Indira Gandhi Institute of Development Research, India.

3. Agrawal, P., (2001), The Relation between Saving and Growth: Co-integration and Causality Evidence from Asia, Applied Economics, Vol. (33), pp. 499-513.

4. Alguacil, M., Cuadros, A. and Orts, V., (2004), "Does Saving Really Matter for Growth? Mexico (1970 - 2000)", Journal of International Development, Vol. 2. pp. 281-290.

5. Bankole, A.S. and Fatai, B.O., (2013), "Relationship between Savings and Economic Growth in Nigeria", The Social Sciences and Medwell Journals, 8(3), pp. 224-230.

106 Sciendo Studia Universitatis "Vasile Goldis" Arad. Economics Series Vol 29 Issue 3/2019 ISSN: 1584-2339; (online) ISSN: 2285 - 3065

Web: publicatii.uvvg.ro/index.php/studiaeconomia. Pages $92-108$ 
Simelane, B., Odhiambo, N.M., (2019)

The dynamics of savings mobilisation in Lesotho

6. Carroll, C.D. and Wel, D.N., (1994), "Saving and Growth: A Reinterpretation", Carnegie-Rochester Conference Series on Public Policy 40: pp. 133-192.

7. Central Bank of Lesotho (CBL), (1990-2017), Annual Reports. Maseru, Lesotho.

8. Central Bank of Lesotho, (2004), Supervision Annual Report. Maseru, Lesotho.

9. Central Bank of Lesotho (CBL), (2012), Kingdom of Lesotho Rural Financial Intermediation Programme (RUFIP). Maseru, Lesotho

10. Centre for Financial Regulation and Inclusion, (2014), "Lesotho. Demand, Supply, Policy and Regulation", Making Access Possible (MAP) Diagnostic Report.

11. Domar, E.D., (1946), Capital Expansion, Rate of Growth and Employment, Econometrica, Vol. (14), pp. 137-147.

12. FinScope, (2011), "FinScope Consumer Survey for Lesotho", Conducted in Collaboration with the Central bank of Lesotho.

13. Gavin, M., Haussmann, R. and Talvi, E., (1997), "Saving Behavior in Latin America: Overview and Policy Issues", In Promoting Savings in Latin America.

14. Harrod, R.F., (1939), An Essay in Dynamic Theory, Economic Journal, Vol. (49), pp. 14-33.

15. Haussmann, R. and Reisen (Eds.), Organization of Economic Cooperation and Development and Inter-American Development Bank, Paris.

16. Ijeoma, O., Moshoeshoe, R.E. and Paramaiah, Ch., (2011), "Financial Development, Savings and Economic Growth in Lesotho: Evidence from Trivariate Causality Test", International Journal of Economics and Business Studies, Vol. 1, Issue 2, pp. 41-55.

17. International Labour Organization (ILO), (2011), The Performance of Lesotho Credit Union Movement: Internal Financing and External Capital Inflow, Working Paper No. 17.

18. International Monetary Fund (IMF), (2012), IMF Lesotho Country Report No. $12 / 101$.

18. Jappelli, T. and Pagano, M., (1994), Saving, growth, and liquidity constraints, The Quarterly Journal of Economics, Vol. 109, No. 1, pp. 83-109.

19. Kalebe, M., (2015), "Determinants of Private Savings in Lesotho", International Journal of Recent Research in Interdisciplinary Sciences (UJRRIS), Vol. 2, Issue 1, pp. 10-16.

20. Kudaisi, B.V., (2013), Savings and Its Determinants in West Africa Countries, Journal of Economics and Sustainable Development, Vol. 4, No. 18.

21. Lukhele, A.K., (1990), Stokvels in South Africa: Informal Savings Schemes by Blacks for the Black Community, Johannesburg.

22. Makoa, F.S., (2004), Electoral reform and political stability in Lesotho, African Journal on conflict resolution 4(2), 79-96, viewed 15 December 2017, from https:// www.ajol.info/index.php/ajcr/article/view/39379/30304 
Simelane, B., Odhiambo, N.M., (2019)

The dynamics of savings mobilisation in Lesotho

23. Mowatt, R. and Zulu, T., (1999), "Intra-Regional Private Capital Flows in Eastern and Southern Africa: a Study of South African Investment".

24. McKinnon, R.I., (1973), Money and Capital in Economic Development, Brookings Institution.

25. Odhiambo, N.M., (2009), "Savings and Economic Growth in South Africa: A Multivariate Causality Test", Journal of Policy Modeling, 31(5), pp. 708-718.

26. Saltz, I.S., (1999), "An Examination of the Causal Relationship between Savings and Growth in the Third World", Journal of Economic Finance, Vol. 23, pp. 90-98.

27. Sekantsi, L.P. and Kalebe, K.M., (2015), "Savings, Investment and Economic Growth in Lesotho: An Empirical Analysis", Journal of Economics and International Finance. Vol. 7(10), pp. 213-221.

28. Shaw, E.S., (1973), Financial Deepening in Economic Development, Oxford University Press.

29. Sinha, D. and Sinha, T., (1998), "Cart before the Horse? The Saving - Growth Nexus in Mexico", Economics Letters 61, pp. 43-47.

30. Solow, R.M., (1956), "A Contribution to the Theory of Economic Growth", Quarterly Journal of Economics, 70(1), pp. 65-94.

31. United Nations Conference on Trade and Development (UNCTAD), (2013), Service Policy Review for Lesotho.

32. World Bank, (2004), "Lesotho Financial Sector Review", The World Bank Financial Sector Division Africa Region, paper number 28547. 